\title{
Between Aaron and Moses in 4QVisions of Amram
}

\author{
Liora Goldman
}

The composition known as the Visions of Amram ${ }^{1}$ contains two main themes of the rewritten Bible genre from Qumran: narratives on the patriarchs and their testaments and narratives on the exodus and the giving of the Torah on Mount Sinai. Devorah Dimant proposed a linguistic-thematic classification that distinguishes between rewritten Bible texts composed in Aramaic and Hebrew. This scheme proposes that written traditions associated with figures from the pre-flood period and contemporary with this era, together with those relating to the patriarchs, were primarily composed in Aramaic, while those concerning the period from the exodus through the giving of the Torah on Mount Sinai to the exile were composed in Hebrew. ${ }^{2}$

The Visions of Amram is unique in that it combines aspects of both categories. While written in Aramaic and dealing with patriarchal figures, it also contains themes concerning Moses and the exodus. In its content and style, the composition belongs to the testament genre. ${ }^{3}$ While these texts relate

1 In the official publication of the Visions of Amram Émile Puech identified this composition as consisting of seven scrolls: 4Q543-549. For the full editio princeps, see Émile Puech, Qumrân grotte 4.XXII: Textes araméens, première partie: 4Q529-549, DJD 31 (Oxford: Clarendon Press, 2001), 283-405. Duke, in his edition, regards only five copies (4Q543-547) as belonging to this composition; see Robert R. Duke, The Social Location of the Visions of Amram (4Q543-547), StBibLit 135 (New York: Peter Lang, 2010), 35-42. Trehuedic is unsure whether 4Q548-4Q549 belong to the Visions of Amram; see Kevin Trehuedic, "Les visions du testament d'Amram A-E; F(?); G(?)," in Torah:Exode, Lévitique, Nombres, ed. Katell Berthelot and Thierry Legrand, vol. 2 of La Bibliothèque de Qumrân (Paris: Cerf, 2010), 207-31, (207-8). In my opinion, while $4 \mathrm{Q}_{548}$ does not belong to the Visions of Amram, $4 \mathrm{Q}_{549}$ should be regarded as a sixth copy, belonging to the end of the text; see Liora Goldman, "Dualism in the Visions of Amram," $\operatorname{RevQ} 95$ (2010): 421-32 (425, 431-32).

2 Devorah Dimant, "The Qumran Aramaic Texts and the Qumran Community," in Flores Florentino: Dead Sea Scrolls and Other Early Jewish Studies in Honour of Florentino García Martínez, ed. Anthony Hilhorst, Émile Puech, and Eibert J. C. Tigchelaar, JSJSup 122 (Leiden: Brill, 2007), 197-205.

3 This assessment was made as early as the first scholarly work on the Visions of Amram, beginning with Starcky, who considered that the manuscripts resembled the Testament of Levi; see Jean Starcky, "Le travail d'edition des manuscrits de Qumran," RB 63 (1956): 49-67 (66-67). Milik subsequently pointed to the correspondences between the Visions of Amram and the testament genre in one of his early publications; see Józef T. Milik, "4QVisions de 'Amram et une citation d'Origène," RB 79 (1972): 77-97 (77). Puech, DJD 31, also accepted this 
principally to pre-Sinaitic biblical figures, namely the patriarchs and the tribal leaders, the Aramaic testaments found at Qumran - the Aramaic Levi Document, ${ }^{4}$ the Testament of Qahat, and the Visions of Amram-are characterized by their preoccupation with the priestly line of Levi. Since Amram's son Moses is also a scion of this priestly lineage, his life and the story of the exodus properly are treated within an Aramaic testament dealing with Levi's offspring.

In this article I wish to discuss Moses' and Aaron's role(s) as described in the visions revealed to their father Amram in his testament, in order to answer the following questions: which son is the protagonist of the composition, who is called "the angel of God," and what is the main theme of the composition - the Levitical line and the establishment of the high priesthood or the national narrative of the exodus.

\section{2 The Role of Amram in the Visions}

The Visions of Amram was composed in the testamentary form known to us from the Greek Testaments of the Twelve Patriarchs. On his deathbed, Amram gathers his offspring to deliver his last will and testament to them. The composition contains a blessing for his sons, a narrative of events from Amram's life, and an account of the visions revealed to him concerning Moses' and Aaron's destinies.

Since this text belongs to the testamentary genre, Amram, the patriarchthe father of the family - becomes the main character/protagonist of the composition. His significance is first and foremost in the inheritance he leaves to his sons and to those who continue his legacy. Furthermore, he is a crucial link in the Levitical line and his testament complements (in part) the gap in the biblical narrative between the time of Jacob and Levi and that of Aaron. From an anonymous figure denoted as "a certain man of the house of Levi" (Exod 2:1), mentioned in the biblical text merely for being Moses' father, Amram becomes the principal protagonist.

evaluation in his edition. Frey too adopted this approach, stressing that the Visions of Amram constitutes a prominent example of the Qumran testamentary genre; see Jörg Frey, "On the Origins of the Genre of the 'Literary Testament': Farewell Discourses in the Qumran Library and Their Relevance for the History of the Genre," in Aramaica Qumranica: Proceedings of the Conference on the Aramaic Texts from Qumran in Aix-en-Provence 30 June-2 July 2008, ed. Katell Berthelot and Daniel Stökl Ben Ezra, STDJ 94 (Leiden: Brill, 2010), 345-76 (357-59).

4 It should be noted that while the Aramaic Levi Document is not generally identified as a testamentary text, it contains features characteristic of this genre; see Frey, "On the Origins of the Genre," 363-66. 
Unlike the other two Aramaic compositions that are attributed to the Levitical line-the Aramaic Levi Document and the Testament of Qahat (4Q542) - the Visions of Amram presents Amram as the father of two prominent figures in Israelite history, Aaron and Moses. The visions conveyed to him, which he imparts to his offspring in his final testament, relate directly to them. Despite this clear feature, the primary message of the composition remains to be determined. Is it intended to stress the foundation of the eternal priesthood by Aaron's or rather Moses' deliverance of the Israelites from Egypt? Does the author seek to conjoin these events and their key figures? These questions will be examined here by reviewing the content of the composition and its literary structure. Unfortunately, only fragments have survived of the main section of the work, containing the visions given to Amram together with prophecies relating to his sons, Moses and Aaron, and their destiny as the deliverers of Israel. The only parts of this text preserved nearly in their entirety are the farewell scene, the narrative concerning Amram's return to Canaan to bury his forefathers, and the description of Amram's meeting with the angels. ${ }^{5}$

We learn about Moses and Aaron, their relations with their father, and their relative significance in the composition mainly from the first, second, and fifth units: the first unit possibly includes a reference to Moses' Hebrew name in the composition; the second unit raises the question of which son was chosen to be blessed; the fifth unit presents, as part of the visions revealed to Amram, the future deeds of Moses and Aaron.

In fact, the questions are all connected, and though the fragmentary texts are ambiguous, I will do my best to clarify the difficulties.

The first unit (4Q543 1a-c and 2a-b / 4Q545 1a / 4Q546 1), in a way typical of the testament genre, describes the deathbed scene and serves as the literary and chronological organizing framework of the composition. On his deathbed Amram gathers his family to hear his testament. This scene raises the question: does Moses have a Hebrew name?

5 The passages proceed as follows: the composition opens with a chronological framework followed by a deathbed scene, in which Amram delivers his final words to his children (4Q543 1a-c and 2a-b / 4Q545 1a / 4Q546 1). Then follows a scene in which the burial of Amram's forefathers in Canaan is described (4Q543 3-4 / 4Q544 1 1-9 / 4Q545 1a-b ii 11-19 / 4Q546 2 / 4Q547 1-2 1-8). After that comes the dream vision concerning the two angels (4Q543 5-10 / $4 Q_{544} 1-3 ; 4 Q_{546} 4$ / 4Q547 1-2 9-13). It should be noted that the overlap between the various manuscripts permits the reconstruction of a continuous narrative from these four literary units. The continuation is too fragmentary to be reconstructed with any certainty, but it contains the visions revealed to Amram concerning Moses and Aaron. This part is the fifth unit, according to my suggestion for the structure of the composition. The closing of the composition is a list of genealogical details found only in $4 \mathrm{Q}_{549}$. 
In 4Q545 1a i 8-10 (/4Q543 1a-c 8) we read: ${ }^{6}$

$$
\begin{aligned}
& 8 \\
& 9 \\
& \text { [אבונא (?) }
\end{aligned}
$$

8 the days of the feast were over, he sent for Aaron his son, [who] was a[bou]t [twen]ty years old

9 [and he said] to him, "Summon me, my son, the messengers, your brothers from the house of

10 [our father"

According to this passage, Amram sends Aaron to call a man/men from his house, as indicated in line 9. Puech considers the word אחיכוֹ a plural and thus understands the phrase as follows: "Appelle-moi, mon fils, les messagers, vos frères de la maison de ...." It is difficult to accept this reading and exegesis, since it implies that Amram had additional children. Moreover, why would Moses, the youngest of the siblings, be summoned to hear his father's will together with his cousins or other close relatives, and why are the brothers referred to as "messengers"? 8

Beyer and Duke argue that the word מלאכיה refers to Moses, to whose Hebrew name we are made privy in this passage. They consequently understand the phrase as follows: "My son, call [for me] your brother, Malachia, from [our father's] house" (ארא לי, ברי, לאחוכון מלאכיה מבית [אבונא]). A scrutiny of

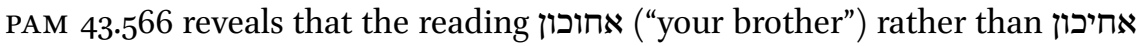
("your brothers") is possible, since only a trace of the top of the letter waw/ yod remains..$^{10}$

"Malachi"11 appears several times in the Hebrew Bible, but is known principally from the prophetic biblical book carrying this name. The opening verse of this book presents the prophecy as "a pronouncement: the word of

6 The Aramaic texts in this article are taken from Puech, DJD 31:283-405. The English translation is taken from Emanuel Tov, ed., The Dead Sea Scrolls Electronic Library on CD-ROM (Leiden: Brill, 2006).

7 Puech, DJD 31:335.

8 See also Duke, The Social Location, 72-73.

9 Klaus Beyer, Die aramäischen Texte vom Toten Meer (Göttingen: Vandenhoeck \& Ruprecht, 2003), 2:118-19; Robert R. Duke, "Moses' Hebrew Name: The Evidence of the Visions of Amram," DSD 14 (2007): 34-48.

10 Puech, DJD 31:335.

11 "Malachi" is a Hebrew name found in the Hebrew Bible. "Malachia" is the name found in the Visions of Amram. Both have the same meaning: the messenger of God. Accordingly, 


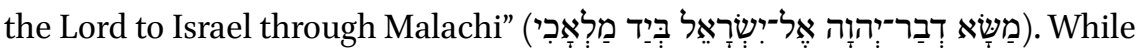
this expression serves as reference to the prophet's name, it can also constitute an allusion to his prophetic mission as the messenger of God. Indeed, the Septuagint understood this text to contain an allusion not to the prophet but to his commission from God, thus rendering the verse: "The burden of the word

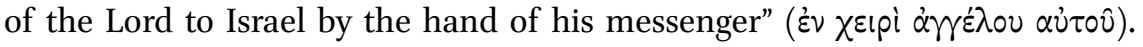

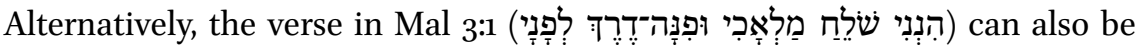
understood either as a reference to Malachi himself (i.e., to his name) or to the angel of the covenant mentioned later in the text. ${ }^{12}$

According to these verses, the term can be interpreted both as a reference to the prophet's name and as an expression of his task as God's messenger. ${ }^{13}$ It is possible that the text in Exod 23:20, 23 should be read in a similar fashion:

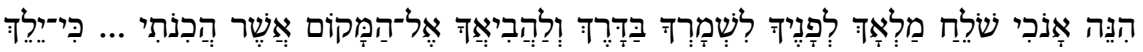
(II am sending an angel before you to guard you on the way and to bring you to the place that I have made ready.... When my angel goes before you and brings you to the Amorites ... and I annihilate them"). ${ }^{14}$ While in the various references to the angel of God in the exodus account (for example, Exod 32:34; 33:1-2) God addresses Moses, to whose aid the angel is sent, in this passage (Exod 20:23) God speaks to the people. It can therefore be assumed that the מלאד is in fact Moses himself. ${ }^{15}$ The attribution of the name "Malachia" to Moses in the Visions of Amram can thus possibly be traced to an exegetical tradition identifying the angel of God mentioned in the exodus account with Moses (cf., especially, Exod 23:20 and Num 20:16). ${ }^{16}$

in this article I use "Malachi" for discussions of biblical contexts and "Malachia" when referring to the Visions of Amram.

12 The majority of scholars attribute the name "Malachi" to an anonymous prophet, on the basis of Mal 1:1; see, for instance, David L. Petersen, Zechariah 9-14 and Malachi: A Commentary, отL (Louisville, KY: Westminster John Knox, 1995), 166.

13 Biblical texts written in the Second Temple period sometimes employ the term מלאך in reference to prophets: cf. Hag 1:13; 2 Chr 36:15-16.

14 It should be noted that in the Septuagint, the Samaritan Pentateuch, and the Vulgate the

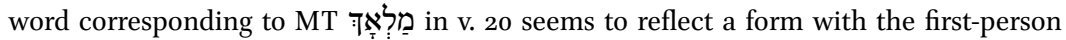

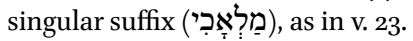

15 Commentators throughout the ages have discussed the question of whether Moses should be considered an angel. Some regard the text as referring to God himself while others argue that it refers to either a divine agent or a human agent, or even specifically to Moses; see Uriel Cassuto, A Commentary on the Book of Exodus (Jerusalem: Magnes, 1987), 305-6; Brevard S. Childs, Exodus: A Commentary (oтL; London: sCM Press, 1974), 487; and the following note.

16 Some early rabbinic midrashim contain evidence that Moses was associated with the angel. For example, Exod. Rab. 32:2 interprets the verse "Behold, I send an angel before 
The second unit (4Q543 2a-b // 4Q545 1a // 4Q546 1) describes Amram's recounting of his testament. The narrative in this unit switches from the third person singular to the first person singular as Amram becomes the speaker.

This section preserves, in fragmentary form, the blessing given to one of Amram's sons. Unfortunately, the name of the son has not been preserved.

3 The Blessing in 4 Q543 2a-b 1-9

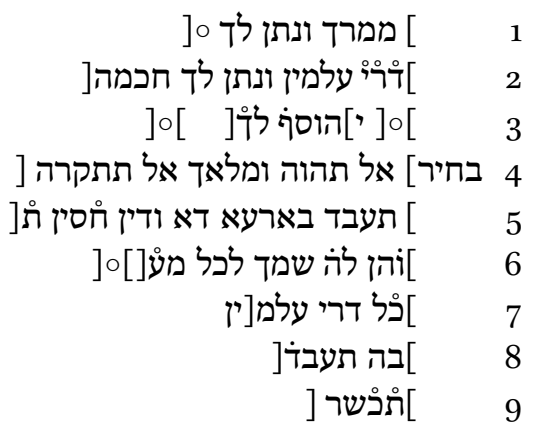
1 ] your command and we will give you [
2 ] forever and we will give you wisdom[
3 ] will be added to you[ ] [
4 the elect] of God you will be, and the angel of God you will be called [
5 ] you shall do in this land, and a stern judgment
$6 \quad$ ] and if your name is his to all [ ] [
7 ] all eternal generati[ons
8 ] you shall do[
$9 \quad$ ] you will be/ make fit [

The blessing notes the wisdom bestowed on the son, his election by God, and his becoming an "angel of God" in the sense of being commissioned by God. Puech argues that the addressee is Aaron. ${ }^{17}$ This indeed constitutes the most

you" as signifying that the angel is an agent, rather than God himself, and that he was sent by God due to the people's sins. It is thus clear that the angel is human, Moses being the most likely candidate. Other texts, based on Num 20:16, express the view that prophets are compared to angels and thus identify the angel with Moses; cf. Lev. Rab. 1:1; Num. Rab. 16:1. For the former text, see also below. Medieval commentators also dispute the angel's identity, Gersonides and Joseph ben Isaac Bekhor Shor both argued that the reference is to a prophet.

Puech, DJD 31:336-37. 
obvious option if the composition is identified as a document highlighting the priestly line. The motif of the judicious priest filled with divine insight also occurs in the Aramaic Levi Document (4Q213 19-16) and the Apocryphon of Levi (4Q541 9 i 2). While the representation of the priest as an angel of God

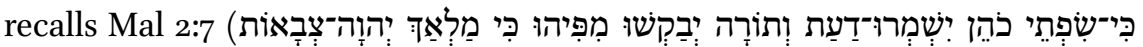
הואט), this obvious allusion may, in fact, not be the true source. ${ }^{18}$ It is indeed quite plausible to read the blessing as addressed to Moses. The term "angel" in reference to a priestly figure occurs only once in the biblical text (Mal 2:7), and, as argued above, is applied far more frequently in relation to the prophet (compare with Hag 1:13 and $2 \mathrm{Chr} 36: 15^{-16}$ ). Likewise, some of the verses referring to the angel who leads the people out of Egypt are interpreted and understood as alluding to Moses (Exod 23:20 and Num 20:16).

It is possible that the blessing of the other son was recounted in lines 4-11 that are missing from $4 \mathrm{Q}_{545}$ 1a ii. ${ }^{19}$ Even so, the identity of the first son to be blessed remains an open question. If, as suggested above, Moses' Hebrew name was indeed Malachia ("the angel/messenger of God"), the question can be answered. Amram's words to his son: "You will be God's chosen and be called a messenger of God" (4Q543 2a-b 4; 4Q545 1a i 17-18) constitute plausible proof that Moses' Hebrew name was indeed Malachia. It is worth noting that the word מלאך is linked to Moses also in 4QApocryphal Pentateuch B (4Q377 2 ii 11), but even there it is used as a simile, referring to an angel to whom Moses is compared (כמלאכ). ${ }^{20}$

The fifth unit recounts the visions imparted to Amram concerning his two sons, Aaron and Moses. It is possible that it also included visions regarding Miriam, as the mystery revealed to her is mentioned in 4 Q545 12 4. Four brief

18 Several rabbinic midrashim associate the angel with the priest Phineas, based on Mal 2:7; cf. Lev. Rab. 1:1; Num. Rab. 16:1.

19 The end of the first column of 4 Q545 1a contains the beginning of the blessing from the second unit of the composition, while the end of the second column contains the description of Amram's journey to bury his forefathers, appearing in the third unit of the composition. Thus, the space in lines $4^{-11}$ of the second column would have been available for an additional fragment that did not survive-possibly one recounting the blessing of the second son.

20 Although scholars are divided over the question whether Moses is actually regarded as an angel or merely compared to one in this text, the phrase does not warrant the former interpretation, since the analogy is made on the basis that God speaks through him (וכמלאכ ידבר מפיהו); see James C. VanderKam and Monica Brady, Wadi Daliyeh and Qumran Cave 4.XXVIII: Miscellanea, Part 2, DJD 28, ed. Moshe Bernstein et al. (Oxford: Clarendon Press, 2001), 131-49, 205-17; Géza G. Xeravits, "Moses Redivivus in Qumran?" QC 11.1/4 (2003): 91-105 (97-99); Phoebe Makiello, "Was Moses Considered to Be an Angel by Those at Qumran?" in Moses in Biblical and Extra-Biblical Traditions, ed. Alex Graupner and Michael Wolter, BZAW 372 (Berlin: de Gruyter, 2007): 115-27. 
passages from this unit possibly form part of the visions revealed to Amram concerning Moses and Aaron and their role in the exodus from Egypt.

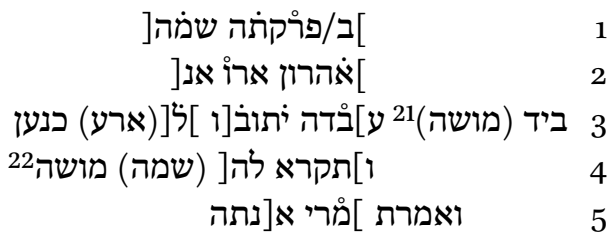

1 ] you redeemed his name[
2
]Aaron, for behold[

3 by the hand of Moses] his servant, [they] will return to [the (land of) Canaan 4 and] you will call him [Moses

5 and I said,] "My lord, y[ou

The reference to Moses in this fragment can be determined with a relatively high degree of certainty due to line 3 , the allusion to "his servant" forming the key to understanding the context of the passage. The pronoun "his" refers to God and the figure is thus described as God's servant. Moses is called עֶבֶד יְָוזה ("the

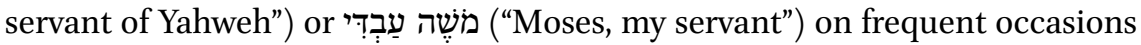

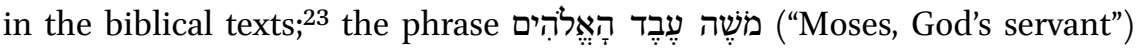
ביד also occurs (cf. Neh 10:30; 1 Chr 6:34). Therefore, Puech's reconstruction ("by the hand of Moses] his servant”) is quite plausible. Although the phrase most frequently refers to Moses' giving of the commandments, ${ }^{24}$ here the following verb יתובו ("they will return") indicates that this is not the subject of the sentence. I concur with Puech's view that the reference is to the Israelites' return to the land of Canaan, despite the fact that the root שו"ב/תו"ב ("return") occurs neither in the biblical accounts nor in the Aramaic Targum

21 The brackets () are used by Puech for uncertain reconstructions.

22 I reconstruct here [Malachia/מלאכיה]. See my explanation below.

23 Deut 34:5; Josh 1:1, 2, 13, 15; 8:31, 33; 11:12; 12:6 [twice]; 13:8; 14:7; 18:7; 22:2, 4, 5; 2 Kgs 18:12; 2 Chr 1:3; 24:29.

24 See, for example:ככ] (2Q504 18 15). For the text 4Q504, see Dennis T. Olson, "Words of Lights (4Q504-4Q506)," in The Dead Sea Scrolls: Hebrew, Aramaic and Greek Texts with English Translation, 4A: Pseudepigraphic and NonMasoratic Psalms and Prayers, ed. James H. Charlesworth (Tübingen: J.C.B. Mohr [Paul Siebeck], 1997), 107-53. 
of Exodus. The same root does, however, occur in the section of the Covenant between the Pieces, which speaks of the Israelites' restoration in Canaan:

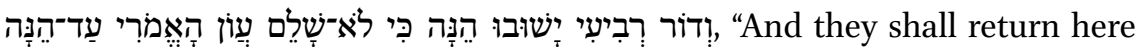
in the fourth generation, for the iniquity of the Amorites is not yet complete" (Gen $15: 16) .25$

In line 4, Amram is commanded to give a name to someone. Although neither the person nor his name has been preserved in the fragmented text, it is highly probable that the figure is Moses, who appears to have been mentioned in the preceding line and to whom the designation בע ע refers. Name-giving is a well-known motif in the Hebrew Bible. In the majority of cases, such a bestowing is accompanied by popular etymology explaining the meaning of the name in its context. This theme occurs repeatedly in the Visions of Amram, where the root pith the meaning "call or be called (by name)" appears seven or eight times. ${ }^{26}$

According to the details given in Exod 2:10, "Moses" is the name given to the child by Pharaoh's daughter. The name derives from the root משי"ה "draw from the water"-reflecting the biblical narrative of Moses' retrieval from the Nile. ${ }^{27}$ In the Visions of Amram, however, the reference is rather to the name that Amram is commanded to give his son. If our proposed conjecture is correct-namely, that in this passage Amram is informed of Moses' future role in the exodus - we would expect Moses' Hebrew name to be related to this significant event.

On the basis of this interpretation, I would like to suggest that Amram received a revelation of his son's Hebrew name and his role as Israel's deliverer. This name marks and symbolizes him as God's messenger-Malachia. The use of both of the names-Moses and Malachia-in the composition can be explained by literary means: the Hebrew name is used when Amram is requested to give his son a name that will symbolize his essence, ${ }^{28}$ while the biblical name is used in the rewriting of the exodus story.

25 In most cases, שו"ב is employed with respect to the return from the Babylonian exile, cf. Jer 12:15; Zech 10:10; Ps 126:1.

26 4Q543 2a-b 4 (/4Q545 1a i 17-18); 4Q543 14 1-2; 4Q544 2 12-13; 4Q545 4 18; 4Q545 8 2; 4Q546 8 4; 4Q546 93; 4Q546 11 3-4. In the case of 4Q544 2 12-13, despite the fact that only the letter מתקרא[ מת [ת remains, the reconstruction named") is quite plausible in light of the context. With respect to 4Q543 14 1-2, Puech's reconstruction is feasible, although less certain (Puech, DJD 31:301).

27 In fact, this is an Egyptian name that was given a Hebrew interpretation (midrash). See Childs, Exodus, 19.

28 For further discussion of the meaning of the name "Malachia," see Duke, The Social Location, 73-79. I would like to emphasize that I do not agree with Duke's suggestion that the name symbolizes Moses also as a king. 


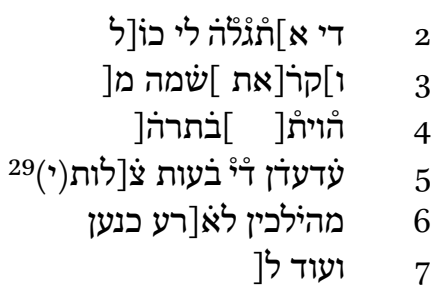

2 which] was revealed to me, al[l

3 and I] called his name $\mathrm{M}[$

4 I was [ ]after him [

$5 \quad$ unto the time of the petition of [my prayer

6 going to the 1 and of Canaan

7 and yet [

The evidence of this fragment, which seems to refer to the commissioning of Moses, is more obscure than the previous passage. While it may contain a description similar to 4Q546 8, it may also be construed as referring to Amram's deeds. That is the way Puech reconstructs the passage. ${ }^{30}$

Here, too, the motif of name-giving appears in line 3. Since the letter is preserved, Puech reconstructs the name "Moses." ${ }^{31}$ In light of the above discussion, however, it is also plausible to reconstruct the name "Malachia."

Line 5 appears to refer to prayer (according to Puech's reconstruction, followed here), most likely indicating an expectation that God will answer the plea. It is not clear from the passage who is praying. Is it Amram, awaiting the fulfillment of what has been revealed to him, or is it Moses? While the biblical texts record no prayer uttered by Moses in connection with events prior to his appointment as the people's deliverer or the commencement of his leadership prior to the exodus, the rewritten biblical texts regularly contain such insertions. ${ }^{32}$ Here, I would like to suggest another option, that the prayer is uttered by all the people of Israel, crying out for deliverance from Egypt (cf. Exod 2:23).

29 See note 21 above. For a different reconstruction, see below.

30 Puech, DJD 31:361-62.

31 Puech, DJD 31:36o.

32 The most prominent example is Moses' prayer on Mount Sinai on behalf of the Israelites before he received the tablets in Jub. 1:19-21. 
When God reveals himself to Moses, he says that he has heeded the people's cry (Exod 3:7) and has chosen Moses to deliver them out of Pharaoh's bondage in Egypt. ${ }^{33} \mathrm{~A}$ clear link between the people's call and their deliverance and

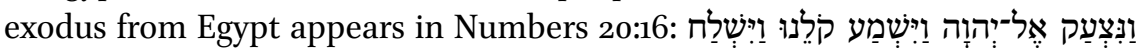
"We cried to the Lord and He heard our plea, and He sent a messenger who freed us from Egypt"). Targum Onqelos to this verse reads: "We prayed to the Lord and He accepted our prayer and sent a messenger who freed us out of Egypt"). This reflects a tradition that explicitly understands the "cry" as a prayer. It is thus suggested that line 5 may be best reconstructed to read: עדעדן ד־י בעות " צ'לותהון ("until their prayer was answered/accepted").34 This reconstruction suggests a different suffix in the brackets, implying that it was the people's prayer rather than Amram's.

If this passage describes the people's cry as a prayer for deliverance, which God hears and answers, it should be examined in relation to the beginning of the unit. As in $4 Q_{5468}$, analyzed above, lines 2-3 in fragment 9 appear to depict a revelation to Amram concerning Moses' name and future role. Here, too, Amram might be expected to refer to his son's name. The only extant letter

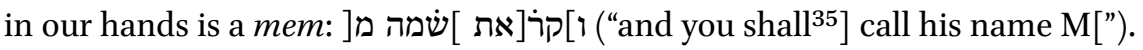
As noted above, Puech reconstructs "Moses." I suggest, however, that the better reading also in this case is "Malachia"-particularly in light of Num 20:16. This verse links the people's plea for deliverance from bondage in Egypt with

33 Such a use of the roots זעע"ק /צע to indicate a plea for divine aid is common in biblical texts: cf. 1 Sam 9:16; Isa 30:19; Jer 11:11; Ps 77:2. This form of prayer is restricted to an appeal for God's deliverance in times of trouble and crisis and does not cover the broader senses of the term "prayer"; see also,Gerhard Hasel, "Zā'aq-Tsāaq," тDот 4:120-21.

34 The motif of the people crying out for deliverance from bondage in Egypt, which reaches God's ears as a prayer, is also found in 4QNarrative C (4Q462). Line 12 reads: [.... יהםקה ויעבודו ויתקימו ויזעקו אל .... ו"...] and they served and they endured and they cried to .... ( ( divine aid; Devorah Dimant, "Egypt and Jerusalem in Light of the Dualistic Doctrine at Qumran (4Q462)," Meghillot 1 (2003): 27-58 (39) (Hebrew). The notion of crying out as a prayer heard and answered by God corresponds to the biblical usage of the root

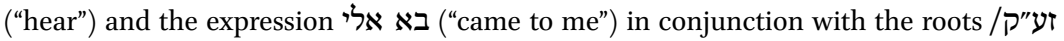
צע"ק, as well as God's refusal to accept such pleas due to the people's sins. Cf. Jer 11:11. This motif is also prevalent in the Scrolls, cf. $11 \mathrm{QT}^{\mathrm{a}} 59: 6 ; 4 \mathrm{Q}_{3} 872$ ii $10 ; 4 \mathrm{Q}_{3} 898$ ii $2-3$.

35 Puech, DJD 31:361, translates: "et je l']appelai de son nom M[oïse," signifying that Amram had already named his son. We have here a difficult case: Puech's translation is correct grammatically but implausible in content, since Amram received the visions prior to returning to Egypt and Moses's birth. It is thus proposed that this sentence constitutes a divine command (imperative mood) to Amram to name his son in the future; see also note 22 . 
the exodus affected through the aid of the angel/messenger. ${ }^{36}$ In the light of such traditions as these, as well as Targum Onqelos to Numbers 20:16, I would propose here that $4 \mathrm{Q}_{546} 9$ constitutes a rewriting of Numbers 20:16. Moses is identified as the angel whom God sends to deliver the Israelites from Egypt following their cry, in divine answer to their prayer.

Puech translates line 6, which contains the root הל"ך, as "going to the land [of Canaan," a reading that does not accurately reflect the plural participle. It is also difficult to evaluate the reconstruction לא] רע כנען (to the 1[and of Canaan]"), since it depends on the interpretation of the previous line, namely, on the identity of the person(s) praying. If the prayer is Amram's, as Puech proposes, the "going" may allude to Amram's return to Egypt after forty-one years' sojourn in the land of Canaan, rather than to his journey to Canaanalthough it should then be assumed that Amram was not alone. ${ }^{37}$ If the people or Moses is praying, this line may once again refer to the exodus. Although it is difficult to determine the most accurate reconstruction in this case, Puech's suggestion is too problematic to be plausible. The present argument permits a better rendering of the plural participle ("going"), relating it to the people, thus providing a more coherent connection to the reading מרא כרע כנען (") ("to the l[and of Canaan]").

6

4Q546 10

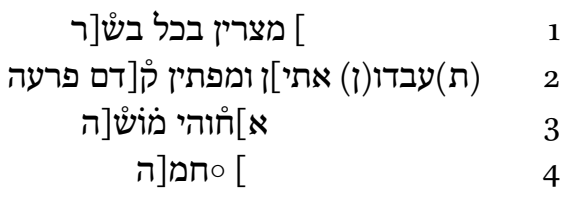

$1 \quad$ Egypt with all fl[esh

2 you shall do sign]s and wonders be[fore Pharaoh

3 ] his brother $\operatorname{Mos}[\mathrm{es}$

4 ] father-in-law (?)

$36 \quad$ A rabbinic midrash on this verse also makes the association between Moses and the angel clear; see Lev. Rab. 1:1.

37 Whatever the case may be in this regard, Puech's reconstruction (DJD 31:361) that Amram was on his way to Canaan to bury his forefathers when this vision was revealed to him is questionable in light of 4Q547 9 8-9. 4Q547 9 clearly indicates that Amram's visions were revealed to him when he had already reached Canaan, rather than while he was still on his way there. For the argument that Amram received the visions while in Canaan, see Goldman, "Dualism," 428. 
Although this passage is extremely fragmentary, the presence of the noun (wonders) in line 2 suggests that its context is the plagues of Egypt or possibly the signs preceding them. Puech's reconstruction, אתי[ו ומפתין ("sign]s and wonders"), is almost certainly correct, given the waw conjunctive joining the two terms. The plagues are frequently described as "signs and wonders" not only in the exodus account itself (cf. Exod 7:3; 11:9-10) but also in other scriptures (cf. Jer 32:20-21; Ps 78:43; 105:27).

On the other hand, the expression "all flesh" 38 in line 1 is not part of the description of the plagues in Exodus. The line may depict the striking of all the Egyptians or, in fact, of "everything"-men, women, and beasts. ${ }^{39}$ The designation of everything living as "flesh" in the context of general destruction appears indeed in the story of the Flood (cf. Gen 6:13, 17). This may constitute the source from which the author of the scroll borrowed the motif of afflicting "all flesh," transferring it to the context of the Egyptian plagues in order to demonstrate the comprehensive devastation and ruin that was wrought.

The reference to Moses appears in line 3, although he is titled as "his brother Moses." The text suggests that Aaron is the subject of the sentence. According to the biblical story, the plagues were, in fact, brought about by Aaron and Moses, though Moses is the principal protagonist and Aaron his aide. God instructs Moses how to act while Aaron participates in the execution of the task. Two scrolls likewise attribute the plagues to Moses (cf. 4Q378 26 3-6; 4Q422 34-5). If Aaron is regarded as the central figure in this passage, and the plagues are ascribed to him with Moses playing a secondary role as his companion, the author of the Visions of Amram appears to have shifted the emphasis of the biblical account. The composition possibly belongs to the priestly dynasty, with the document stressing the acts of the priest (Aaron), as can be seen more clearly in the following unit.

The final passage in which Moses and Aaron are alluded to ${ }^{40}$ probably concludes the visions revealed to Amram. The passage is only preserved in 4Q547:

38 This is rendered "with all flesh." The fragmentary nature of the text notwithstanding, the preferable translation would appear to be "in all flesh."

39 For this meaning of the word "flesh," see Nikolaus P. Bratsiotis, "Bāsaār," TDOT 2: 327-32.

40 ברי ("my son") appears in 4Q546 14 1, and the word לעמך ("your people") in line 2 of the same fragment may also allude to Moses; however, the general context is very unclear and the fragment remains obscure. I have thus chosen not to relate to it here. 


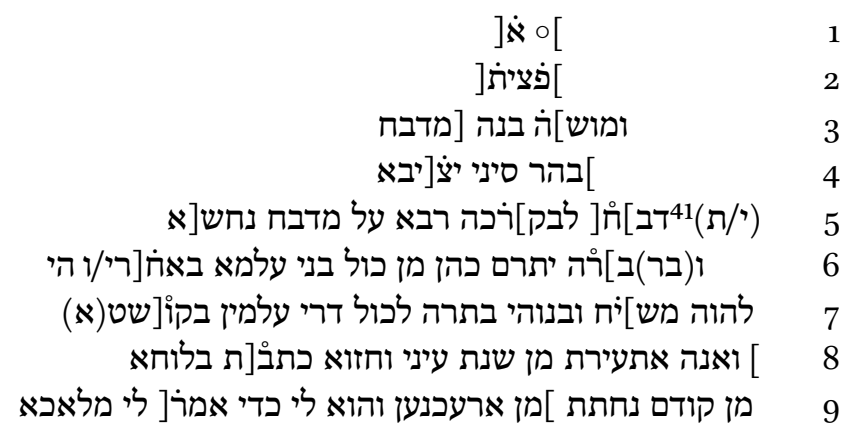

2 ]saved[

3 and Mos] es built [an altar

4 ] on Mount Sinai [

5 you shall sacrifice] your great [cattle] on the copper altar [

6 ] his son shall be exalted as priest over all the people of the world. Then [

7 he will be anoint] $\mathrm{ed}$ and his sons after him for all the eternal generations in $\mathrm{t}[$ ruth

8 ] Then I awoke from the sleep of my eyes and I wrote down the vision [in writing

9 before I went down] from the land of Canaan and it happened to me as [the angel] said [to me

Line 8 clearly concludes the receiving of the dream visions: "Then I awoke from the sleep of my eyes and I wrote the vision." Since this is the only passage in the extant fragments that speaks of waking up from a dream vision, it appears to refer to the awakening from all the visions revealed to Amram and recorded in his testament, rather than from a particular vision.

The vision described in this section seems to be a very brief rewriting of Exod 24-29, chapters that deal with the altar of the covenant, the instructions for the construction of the tabernacle, the priestly garments, and the anointing of Aaron and his sons for eternal priesthood. The passage links together details related to both Moses and Aaron in a fashion similar to the congruence of the sections in the Hebrew Bible. It commences with a description of the erection of the altar at Mount Sinai mentioned in Exod 24:4, built by Moses to implement the covenant between the people and God.

41 Puech could not determine whether the verb דבח in the future tense is conjugated for the second person singular or for the third person singular. See Puech, DJD 31:389. 
The identification of the biblical passage that the Visions of Amram reworks is made possible due to the mention of the erection of the altar ${ }^{42}$ on the mountain, which the exodus account identifies as Mount Sinai. It is unclear why the vision concerning Moses' future role is formulated in the past tense (בנה) in line 3. This usage may indicate the time period of the author, who had before him the biblical text in which the erection of the altar is described in wayyiqtol (Exod 24:4). It is also possible that should be read as an imperative and the reconstruction should be different from that suggested by Puech. For example: אמר למוש] בנה [מדבח [said to Mose]s: 'build [an altar”).43

Line 5 refers to the copper altar for the sacrifice of large cattle. Here, the text in the Visions of Amram appears to be based on the section concerning the copper altar in Exodus 27:1-7. The question is how many altars are referred to in the text. Is it one copper altar or are there two altars: one that is copper plated (rewriting of Exod 27:1-7) and the other made of stones (rewriting of Exod 24:4)? Another difficulty concerns the location of the altar(s). While line 4 asserts that the altar was built on Mount Sinai, Exodus 24:4 locates the altar that Moses built at the foot of the mountain, in the court of the tabernacle. In addition to all this, we must remember that the "altar" in line 3 is a reconstruction of the text. I have no unequivocal solution for this issue, though it is clear that the author of the Visions of Amram saw a relation between the two altars in the biblical description: the covenant altar and the copper altar.

Why does the author of the Visions of Amram "leap" from the erection of the covenant altar on Mount Sinai to that of the copper altar in the tabernacle? The reason may lie in Aaron's role in the two sections. The portion dealing with the making of the covenant in Exod 24:3-8 concludes with God revealing himself to Moses and Aaron and the seventy elders. This is the only biblical passage that speaks of a divine revelation given jointly to Moses and Aaron. According to the Hebrew Bible, the building of the copper altar is juxtaposed with the anointing of Aaron and his sons for priesthood (Exod 29). All the sacrifices related to the anointing ceremony and the consecration to the priesthood are meant to be offered on the copper altar. Likewise, lines 6-7 in the Aramaic work testify to the fact that the anointing of Aaron and his sons is the text's principal focus. Although the fragmented passage mentions no names, the most plausible view is that it deals with Moses anointing Aaron and his

42 Even though the word "altar" in line 3 is completely reconstructed, the context makes this reconstruction almost certain.

43 Another possibility suggested by Jesper Høgenhaven is that the vision included seeing Moses build the altar. The event was therefore referred to in the past tense, from the point of view of the person seeing the vision, while the "real world" event was still a future one. 
sons for eternal priesthood, in correspondence with the description of the anointing and consecration of Aaron and his sons in Exod 29:1-9.

The ceremony of the sprinkling of the blood during the making of the covenant on Mount Sinai (Exod 24:4-8) resembles the ceremony in which Aaron and his sons were anointed for priesthood (Exod 29:15-21). While during the covenant ceremony Moses sprinkled half of the blood on the people and half on the altar, during the anointing of Aaron and his sons for priesthood, he sprinkled some of the blood, together with the anointing oil, on the men and their vestments, to consecrate them. It is possible that the similarities between the two biblical sections and Aaron's role in them both led the author of the Visions of Amram to link them together.

It thus appears that the climax of the passage lies in the acts of Moses, which led to the divine revelation to Aaron (as in Exod 24:9-11) and to the anointing of Aaron and his sons for eternal priesthood. Assuming that this section indeed concludes the visions chapter of the manuscript, it attests to Moses' central role in this priestly testament.

\section{Conclusion}

Very few fragments of the six extant manuscripts of the Visions of Amram deal with Moses and Aaron. An analysis of the extant legible passages of the composition demonstrates that the author presents two new characters who either replace Moses, the biblical protagonist, or attain parity with him: Amram and his son Aaron. From a figure whose weight in the Hebrew Bible derives exclusively from his status as Moses' father, Amram becomes a central figure to whom God reveals visions; who plays a leading role in the burial of his grandfather, Levi, and his brothers in the family tomb in Hebron; and whose testament to his two sons takes on significance for all of Jacob's offspring. Likewise, Aaron goes from being Moses' brother and aide in the exodus to the central protagonist, with Moses being defined as his brother. While Moses evidently is Aaron's sibling, the biblical text always portrays Aaron as secondary to Moses and as Moses' brother (compare with Exod 4:14; 7:1-2; Lev 16:2; Num 27:13; Deut 32:50).

From the present findings, it appears that the figure of Moses was shaped according to two principles. First, his role as the redeemer of the people in bringing them out of Egypt; in this aspect, Moses's Hebrew name, Malachia, emphasizes his commission to deliver the people from bondage. Second, his role as the anointer of Aaron and his sons for eternal priesthood. Thus, on the one hand, the composition represents Aaron as an equal partner to Moses in leading the people out of Egypt; on the other hand, Aaron plays the leading 
role with his sons with respect to the promise of eternal priesthood and to the laws governing the sacrificial cultus. Here, Moses' function is to build the copper altar on which the sacrifices are offered during the investiture of Aaron and his sons.

I have suggested that the burial of the forefathers in Canaan and Amram's encounter with the two angels (4Q543 5-10 / 4Q544 1-3; 4Q546 4 / 4Q547 1-2 9-13) should be regarded not merely as an account from Amram's life but also as a description of significant events occupying a central place in his testament to his sons, namely, the choice of life. ${ }^{44}$ In his final testament, Amram bequeaths his choice to his sons so that they may continue to choose life for themselves and for their descendants, by their future deeds.

The special prominence given to Aaron in this composition indicates that the Visions of Amram presents a particular interpretation of the biblical text that subordinates the exodus of the people of Israel from Egypt to the testament of the priestly line. Its message indicates that the choice of life is exemplified not only in Moses and Aaron's leading the Israelites out of Egypt to make a covenant with God on Mount Sinai, but also in the acts that established the everlasting covenant with Aaron's offspring.

\section{Bibliography}

Beyer, Klaus. Die aramäischen Texte vom Toten Meer. 2 vols. Göttingen: Vandenhoeck \& Ruprecht, 2003.

Botterweck, G. Johannes, and Helmer Ringgren, eds. Theological Dictionary of the Old Testament. Translated by G. W. Bromiley. 15 vols. Grand Rapids, MI: Eerdmans, 1974-2006.

Cassuto, Uriel. A Commentaryon the Book of Exodus. Jerusalem: Magnes, 1987 (Hebrew).

Childs, Brevard S. Exodus: A Commentary. от L. London: SCM Press, 1974.

Dimant, Devorah. "Egypt and Jerusalem in Light of the Dualistic Doctrine at Qumran (4Q462)." Meghillot 1 (2003): 27-58 (Hebrew).

Dimant, Devorah. "The Qumran Aramaic Texts and the Qumran Community." Pages 197-205 in Flores Florentino: Dead Sea Scrolls and Other Early Jewish Studies in Honour of Florentino García Martínez. Edited by Anthony Hilhorst, Émile Puech, and Eibert J. C. Tigchelaar. JSJSup 122. Leiden: Brill, 2007.

44 Liora Goldman, "The Burial of the Fathers in the Visions of Amram from Qumran," in Rewriting and Interpreting the Hebrew Bible: The Biblical Patriarchs in Light of the Dead Sea Scrolls, ed. Devorah Dimant and Reinhard G. Kratz, BzAW 439 (Berlin: de Gruyter, 2013), 231-50 (246); Goldman, "Dualism," 430-32. 
Duke, Robert R. "Moses' Hebrew Name: The Evidence of the Visions of Amram." Dss 14 (2007): 34-48.

Duke, Robert R. The Social Location of the Visions of Amram (4Q543-547). StBibLit 135. New York: Peter Lang, 2010.

Frey, Jörg. "On the Origins of the Genre of the 'Literary Testament': Farewell Discourses in the Qumran Library and Their Relevance for the History of the Genre." Pages 345-76 in Aramaica Qumranica: Proceedings of the Conference on the Aramaic Texts from Qumran in Aix-en-Provence 30 June-2 July 20o8. Edited by K. Berthelot and Daniel Stökl Ben Ezra. ST DJ 94. Leiden: Brill, 2010.

Goldman, Liora. "Dualism in the Visions of Amram." RevQ 95 (2010): 421-32.

Goldman, Liora. "The Burial of the Fathers in the Visions of Amram from Qumran." Pages 231-50 in Rewriting and Interpreting the Hebrew Bible: The Biblical Patriarchs in Light of the Dead Sea Scrolls. Edited by Devorah Dimant and Reinhard G. Kratz. BZAW 439. Berlin: de Gruyter, 2013.

Makiello, Phoebe. "Was Moses Considered to Be an Angel by Those at Qumran?" Pages 115-27 in Moses in Biblical and Extra-Biblical Traditions. Edited by Axel Grauper and Michael Wolter. BZAW 372. Berlin: de Gruyter, 2007.

Milik, Józef T. “4QVisions de 'Amram et un citation d'Origène.” RB 79 (1972): 77-79.

Olson, Dennis T. "Words of Lights (4Q504-4Q506).” Pages 107-53 in The Dead Sea Scrolls: Hebrew, Aramaic and Greek Texts with English Translation, 4A: Pseudepigraphic and Non-Masoratic Psalms and Prayers. Edited by James H. Charlesworth. Tübingen: J. C. B. Mohr (Paul Siebeck), 1997.

Petersen, David L. Zechariah 9-14 and Malachi: A Commentary. oTL. Louisville, KY: Westminster John Knox, 1995.

Puech, Émile. “4QVisions de Amram ara-g." Pages 208-405 in Qumran grotte 4.XXII: Textes araméens, premiér partie: 4Q529-549. DJD 31. Oxford: Clarendon Press, 2001.

Starcky, Jean. “Le travail d'edition des manuscripts de Qumran.” RB 63 (1956): 66-67.

Tov, Emanuel, ed. Dead Sea Scrolls Electronic Library. Leiden: Brill, 2006.

Trehuedic, Kevin. "Les visions du testament d'Amram A-E; F(?); G(?)." Pages 207-31 in La Bibliothèque de Qumrân 2: Torah: Exode, Lévitique, Nombres. Edited by Katell Berthelot and Thierry Legrand. Paris: Cerf, 2010.

VanderKam, James C., and Brady Monica. Wadi Daliyeh and Qumran Cave 4.XXVIII: Miscellanea, Part 2. DJD 28. Oxford: Clarendon Press, 2001.

Xeravits, Géza. “Moses Redivivus in Qumran?" QC 11.1/4 (2003): 91-105. 